\title{
The Relationship between E-Commerce Adoption and Organization Performance
}

\author{
A. H. Mutia Sobihah ${ }^{1}$, Ahmad Munir B. Mohd Salleh Embat ${ }^{2}$, W. Abd Aziz B. W. Mohd Amin ${ }^{1} \&$ Mohamad \\ Saladin Muda ${ }^{2}$ \\ ${ }^{1}$ Faculty of Business Management and Accountancy, Gong Badak Campus, Universiti Sultan Zainal Abidin, \\ Kuala Terengganu, Malaysia \\ ${ }^{2}$ Faculty of Management and Economics, Universiti Malaysia Terengganu, Malaysia \\ Correspondence: Mutia Sobihah Abd Halim, Faculty of Business Management and Accountancy, Gong Badak \\ Campus, Universiti Sultan ZainalAbidin, Kuala Terengganu, Terengganu, Malaysia. Tel: 60-1-393-033-37. \\ E-mail: mutiasobihah@unisza.edu.my
}

Received: September 29, 2013

Accepted: November 25, 2013 Online Published: December 18, 2013

doi:10.5539/ijbm.v9n1p56

URL: http://dx.doi.org/10.5539/ijbm.v9n1p56

\begin{abstract}
E-commerce is growing up very fast all over the world and become important issues in many studies. The tourism industry is the second largest contributor to the economy after the manufacturing sector in Malaysia. Therefore E-commerce cannot be excluded as this technology has huge impact on tourism industry. This paper addresses the role of E-commerce usage for achieving organizational capabilities among hotel in Malaysia. The finding shows the E-commerce business network is higher with a mean 3.48. The study also found that there is a correlation between organization performance with E-commerce business network, and E-commerce competency. This research also employs stepwise regression analysis to look at dominant factor in predicting organizational performance. This research contribute to both academic research and management practice as it provide comprehensive impact of how E-commerce adoption on organizational performance at least in case of Tourism industry in a small developing economy like Malaysia.
\end{abstract}

Keywords: e-commerce business network, e-commerce competency and tourism industry

\section{Introduction}

E-commerce has opened a new relations in electronic trade without restraint boundaries, can be reached anywhere by anyone and E-commerce becomes more important to support an electronic market system. Development of internet has transformed the business environment. Business environment become more complex, organization must become more creative and innovative in order to identify and grab new opportunities for sustained superior performance. In order to reduce the gap in environmental changes that occurs, organizations have to change to avoid from be left behind in many things.

At the end of the 20th century, E-commerce becomes more important (Laudon, 2009) and in the 21st century, an electronic market system had endorsed the world market. Anyone that can access the internet can reach common knowledge of information technology anywhere and has no boundaries. Internet trade is a new era in trade relations and the entire systems of electronic markets have also been structured that provide opportunities for organization from the third world countries (O'Brien, 2008). Related technologies and applications should be changed in line with changes in business operations and how the employees work and how information systems and technology support business processes, decision making, competitive advantages and organizational capabilities (Rezvani et al, 2011; O'Brien 2008 \& Katz, 1993). Refers to the research of O'Brien, (2008) and Katz, (1993) there is relationship between investment in Information Technology and effective capabilities that's relates to each other in order to create a successful business. But it is still questionable, the main difficulty arising by the manager is on how to measure the impact of investment in E-commerce.

E-commerce is an electronic system that is using to buy and sell product or services. Other information technology and internet is using in E-commerce to support business performance. In United States of America, E-commerce growth with $\$ 258$ billion and retailing business about $\$ 3.6$ trillion within 13 years, since 1995 (McKay \& Marshall, 2004). Meanwhile, in year 2005, Malaysia E-commerce transaction reached RM 3.7 
billion and it has moved up 81.8\% year-on-year. Malaysia E-commerce market size was RM 1.8 billion in 2010, estimated to increase RM 5 billion in 2014. Although there is an increase, but it's still considered slow and at the lowest ranked in the list of Asian countries that are 17.7 million users (Malaysia crunch, 2012). This research examines the relationship of E-commerce usage and organizational capabilities in Malaysia's tourism industry focusing on hotel sector.

\section{Literature Review}

\subsection{E-Commerce}

These studies are consistent with the RBV theory, where it highlights that E-commerce business network and E-commerce competency which are the sources of competitive advantage to earn more profit (Xiao, 2008, Zhu 2004, Tow 2004: Wade \& Hulland 2004; Barney 2001; Powell \& Dent Micallef, 1997). To investigate E-commerce adoption in organizational performance based on different industries, several studies used Resource Based View (RBV) model like Rezvani (2011), Tow (2004), Xiao (2008) which focusing in manufacturing industries. Refers to Scupola, (2008), and Rogers, (1995), adoption is the decision to make full use of an innovation as the best sources of action available. These studies are consistent with the RBV theory by Tow (2004). Tow has secured several new dimensions in E-commerce, that only focused on only three dimensions measured against other previously researchers. Through Resource Based View, implementing the use of E-commerce in the organization have seen an increased capabilities of organization involved but have several conditions that E-commerce adoption must have value, rare, difficult to imitate and be a substitute for get a large profit (Intan Salwani et al., 2009; Xiao, 2008; Tow, 2004; Barney, 1991).

Based on the model developed by Mata et. al., (1995), the sources of competitive advantage is business network because they are valuable, imperfectly immobile, and heterogeneously distributed across organization. They also suggest that the history of the organization had shaped a long process of development between people and technology that derived durable E-commerce capabilities. E-commerce technology can be defined as a set of tangible resources and intangible services. Platform technology, network and telecommunication technologies, key data, and core data processing applications are the basic requirement of information technology infrastructure needed to run organization. Meanwhile, the components are related to the information strategy plan which allows organization to be able to respond rapidly and effectively to emergent needs or opportunities are the alignment of information strategy plans to business objectives, information technology architecture plans, information technology skills in information technology resource management.

\subsection{E-Commerce Technology and Organization Performance}

The improvement of the organization performance is grounded by the increasing development of ICT. The organization performance is gaining an unprecedented improvement from the development of the technologies in business and trade (Jahanshani et al., 2011). An organization performance is defined as the outputs or meaningful business results measured against its intended outputs. Organization performance can be measured by different tools, such as financial performance, market performance, employee satisfaction and social responsibility but financial and market performance usually receives a lot of attention of managers and researchers because of their importance in an organization survival and success (Xiao, 2008).

Information flows facilitated by the communication system can potentially increase the sales volume by reaching customers directly and promptly whenever a new product is introduced, and by tapping into markets that were inaccessible on account of distribution or other infrastructure constraints (Wu, Mahajan, \& Balasubramaniam, 2003). The synergistic benefit achieved through an integrated system allow organization to respond better to customer problems and requests (Rogers et al., 1993)

The productivity and economic structure will be affected by the E-commerce. Organization can achieve efficiency and cost effectiveness through the lower fixed costs for establishing and maintaining E-commerce and the higher degree of improvement in unit transaction efficiency through E-commerce (Wen, 2004). Organizations have implemented E-Commerce it helps them pursue internal improvement and achieve a higher level of human resource development, cost reduction, continuous improvement, and organizational efficiency and development (Chang, Jackson, \& Grover, 2003). To harness resources in establishing and maintains its competitive edge is a major concern for marketing scholars that connects various types of market-based assets with the ultimate financial performance of organization (Srivasta, Fahey, \& Christensen, 2001).

E-commerce business network are collaboration between suppliers, business partners, allies and customers that create a value costing systems to produce value (Normann \& Ramirez, 1993). Investigate performance in terms of the creation and offering of integrated solutions that will be affected by network relation (E-commerce 
business network). The strengths of the network relationships, the positions of the firms in the network relationships, the positions of the firms in the network, and the network horizon were the factors that influenced successful development of integrated solutions ( Windahl \& Lakemond, 2006).

Based on the RBV of the organization, organization performance is directly affected by electronic commerce competence. The ability of an organization to employ E-commerce technologies to deliver higher customer value may be a pivotal role of E-commerce competence (Saeed et. al., 2005, \& Handerson, 1994). Skills, information systems infrastructure, experience and slack resources may reflect competencies. In order to contribute toward organization performance, E-commerce competence is representative of pivotal resources differentiated across organization (Saeed et al. 2005).

Proof-theoretical and empirical evidence has been used as the basis for the proposed conceptual framework for this study as shown in Figure 1.

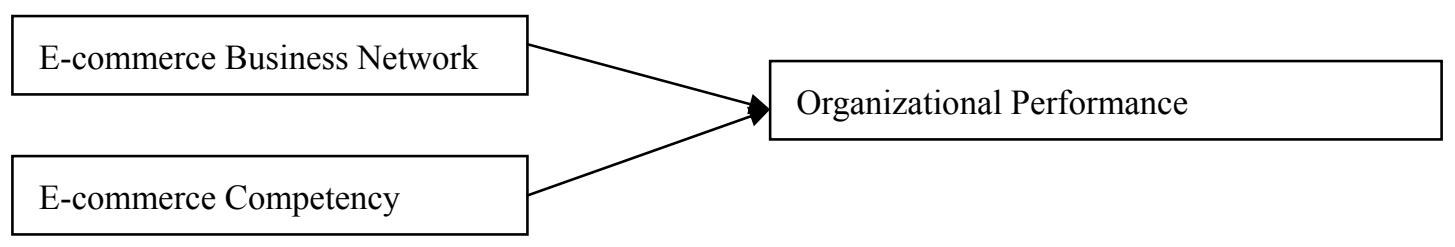

Figure 1. Conceptual framework

Based on the conceptual framework, it can be hypothesized that:

H1: There is a significant relationship between E-commerce business network and organizational performance.

$\mathrm{H} 2$ : There is a significant relationship between E-commerce competency and organizational performance.

\section{Methodology}

This study uses a cross-sectional research design. At the initial stage of data collection, 30 hotels which using E-commerce, involve in a pilot study in order to get their opinions about the content and format of the questionnaire developed by Tow (2004). Based on this pilot study, all items in the survey questionnaires were importance, relevance, and suitable for this study and the researchers adopted all the items. After that, in order to increase the validity and ensure the reliability at research findings, back-to-back translation techniques were used to translate the survey questionnaires into English and Malay languages (Hussey \& Hussey, 1997).

This survey questionnaire consisted at three variables: a) E-commerce business network consists of 7 items, b) E-commerce competency consists of 4 items and c) Organization performance consists of 17 items that were adopted from Tow (2004) and Li Xiao (2008). The items chosen in this study met the acceptable standards at reliability analyses (alpha croncbach greater than 0.60) (Sekaran, 2003). A 5-item likert scale ranging from "strongly disagree" (1) to "strongly agree" (5) were using to measure all items used in the questionnaires.

The population of this study is hotel industries which used E-commerce in Malaysia. Researchers have official approval to conduct a study of the organization management. The researchers had distributed 146 survey questionnaires to 3 stars below hotels and 111 survey questionnaires to 4 stars above hotels using a cluster sampling. 226 usable questionnaires were returned to the researchers and yielding 87 percent at the response rate from the survey questionnaires distributed. But, only 217 samples can be used which is 84 percent. Probability sampling techniques required at least 30 participants and the number of this sample already exceeding the minimum sample, showing that it may be analyzed using inferential statistic (Sekaran \& Bougie, 2011).

Data was analyzed using a statistical Package for Social Science (SPSS) Version 11. Firstly, to assess the validity and reliability at measurement scales, validity and reliability analyses were conducted (Nunally and Bernstein, 1994). Secondly, to determine the collinearity problem, and further confirm the validity and reliability at constructs, Pearson correlation analysis and descriptive statistics were conducted (Hair et. al., 2006). Finally, to assess the magnitude and direction at each independent variable, and dependent variable, multiple regression analysis was recommended. All analyses used Standardized coefficients (Standardized beta). 


\section{Research Findings}

\subsection{Reliability Analysis}

Reliability analysis is the degree to which any reliable or consistent measure (Trochim, 2001). To determine the consistency, Alpha reliability is usually used. As depicted in Table 1 below, E-commerce business network had the highest reliability rate with Cronbach Alpha of 0.99, whereas E-commerce competency showed 0.97. Given these result, E-commerce business network and E-commerce competency variables were reviewed to have adequate levels of internal consistency since they meet the recommended standard of 0.60 (Sekaran, 2003).

Table 1 . Reliability analysis $(\mathrm{n}=217)$

\begin{tabular}{ccc}
\hline Variables & Number of Item & Alpha Cronbach \\
\hline E-commerce Business Network & 4 & 0.99 \\
E-commerce Competency & 3 & 0.97 \\
Organization Performance & 17 & 0.73 \\
\hline
\end{tabular}

\subsection{Descriptive Statistics}

\subsubsection{Mean scores for variables}

The mean scores were computed to identify the levels of organization performance, E-commerce business network, and E-commerce competency. As can be seen in Table 2 below, organization performance appeared to have (mean=3.21). Additionally, E-commerce business network (mean=3.48, $\mathrm{SD}=0.66$ ) and E-commerce competency $($ mean $=3.00, \mathrm{SD}=0.24)$.

Table 2. Summary of mean score analysis

\begin{tabular}{lcc}
\hline Variable & Mean & Standard Deviation \\
\hline E-commerce Business Network & 3.48 & 0.66 \\
E-commerce Competency & 3.00 & 0.24 \\
Organization Performance & 3.21 & 0.31 \\
\hline
\end{tabular}

\subsubsection{Bivariate Correlation Analysis}

The Pearson's Correlation was conducted to measure the relationship between organization performance with E-commerce business network, and E-commerce competency and to test all hypotheses related to that. As illustrated in Table 3, the findings of correlation analysis had shown significantly positive relationships between organizations performance with E-commerce business network, and E-commerce competency variables $(\mathrm{p}<$ 0.01). These results evidently supported the hypotheses $\mathrm{H} 1$ and $\mathrm{H} 2$.

Table 3. Summary of the relationship between dependent and independent variables

\begin{tabular}{|c|c|c|c|c|}
\hline \multirow{2}{*}{\multicolumn{2}{|c|}{ Variable }} & \multicolumn{3}{|c|}{ Pearson Correlation Analysis } \\
\hline & & 1 & 2 & 3 \\
\hline $\begin{array}{l}\text { E-commerce } \\
\text { Network }\end{array}$ & Business & 1 & & \\
\hline $\begin{array}{l}\text { E-commerce } \\
\text { Competency }\end{array}$ & & $0.343 * *$ & 1 & \\
\hline $\begin{array}{l}\text { Organization } \\
\text { Performance }\end{array}$ & & $0.640^{*}$ & $0.506^{* *}$ & 1 \\
\hline
\end{tabular}

Note : Significant at $* * \mathrm{P}<0.01$.

\subsubsection{Multiple Regression Analysis with Stepwise Procedure}

The multiple regression analysis with stepwise procedure was conducted to determine the most dominant variable that influences organization performance. 


\subsubsection{Organization Performance with E-Commerce Business Network, and E-Commerce Competency}

As depicted in Table 4 below, E-commerce business network, and E-commerce competency had stated significant influence on organization performance. E-commerce business network was discovered to be the most dominant predictor of organization performance $(\beta=0.450, p<0.01)$, and E-commerce competency $(\beta=-0.132$, $\mathrm{p}<0.01)$. Together, these two variables stated $\mathrm{R}^{2}$ value of 0.502 , suggesting that $50.2 \%$ of the variance in performance can be explained by them.

Table 4. Stepwise regression of organization performance $(n=217)$

\begin{tabular}{|c|c|c|c|c|c|c|}
\hline Model & $\mathbf{R}^{2}$ & Adjusted $\mathbf{R}^{2}$ & Unstand. Beta & Stand. Beta & $\mathbf{T}$ & Sig. Value \\
\hline Model 1 & 0.409 & 0.406 & & & & \\
\hline Constant & & & 4.180 & & 53.009 & $0.000 * *$ \\
\hline E-commerce Business Network & & & 0.271 & 0.640 & 12.201 & $0.000 * *$ \\
\hline Model 2 & 0.502 & 0.497 & & & & \\
\hline Constant & & & 3.207 & & 18.858 & $0.000 * *$ \\
\hline E-commerce Business Network & & & 0.224 & 0.528 & 10.292 & $0.000 * *$ \\
\hline E-commerce Competency & & & 0.378 & 0.325 & 6.324 & $0.000 * *$ \\
\hline
\end{tabular}

\section{Conclusion and Future Recommendation}

The findings demonstrated the significant relationship between E-commerce business network, and E-commerce competency with organization performance. The outcomes of multiple regression analysis confirmed that E-commerce business network, and E-commerce competency had stated significant influence on organization performance. Of all the predictor's variables, E-commerce business network appeared to be the most dominant variable in influencing organization performance. This result has also supported with previous studies by Tow (2004) and Bharadwaj (2000)

These findings had imposed potential implications for management to review for future plans in order for them to increase organization performance. The broader the scope of the organization activities, the more likely it is for the organization to use E-commerce (Dewan \& Kraemer, 2000). Referring to the results, it is therefore suggested for management to consistency creates value through their willingness to invest in the E-commerce business network to increase performance. It provides useful guides to the click and mortar companies to evaluate their current E-commerce usage and to determine the areas that need to be re-engineered in the process to increase organization performance.

This study provides direction for future E-commerce adoption research by considering the conceptual and methodology limitations of this study. Future research in this area is more interesting if the researcher consider factors as follow: firstly, performed a comparative study between the hotels using the E-commerce with the hotel that still not uses it. Secondly, studies involving E-commerce hotel users. Thirdly, the findings of this study may produce different result if this study is done in other industries in Malaysia.

\section{References}

Barney, J. (1991). Firm resources and sustained competitive advantage. Journal of Management, 17(1), 99. http://dx.doi.org/10.1177/014920639101700108

Barney, J. (2001). Is the resources-based view a useful perspective for strategic management research? Academic of Management Review, 26(1), 41-56.

Bharadwaj, A. (2000). A Resource-Based Perspective on Information Technology Capability and Firm Performance: An Empirical Investigation. MIS Quarterly, 24(1), 169. http://dx.doi.org/10.2307/3250983

Chang, K. C. J. (2003). E-commerce and corporate strategy: An executive perspective. Information and Management, 40, 663-675. http://dx.doi.org/10.1177/014920639101700108

Dewan, S. (2000). Information Technology and Productivity: Evidence From Country Level Data. Management Science, 46(4), 548-562. http://dx.doi.org/10.1287/mnsc.46.4.548.12057

Hair, J. A. (2006). Multivariate Data Analysis. Upper Saddle River, NJ: Prentice Hall.

Handerson, R. A. (1994). Measuring Competence? Exploring from effect in pharmaceutical research. Strategic Management Journal, 15(8), 63-84. http://dx.doi.org/10.1002/smj.4250150906 
Hussey, J. A. (1997). Business Research: A Practical Guide for Undergraduate and Postgraduate Students. Basingtoke, UK: McMillan Press.

Intan Salwani, M. M. (2009). E-commerce and value creation: empirical evidence in Malaysia. Proceedings of the European Applied Business Research Conference. Rothenburg.

Jahanshani, A. R. (2011). Analyzing the effects of electronic commerce on organizational performance: Evidence from small and medium enterprises. African Journal of Business Management, 6(15), 6486-6496.

Katz, A. (1993). Measuring Technology's Business Value. Information System Management. http://dx.doi.org/10.1080/10580539308906910

Liu, X. (2008). The Impact Of Dynamic IT Capability And Organizational Culture On Firm Performance. The George Washington University: Proquest Digital Disertation.

Laudon, K. A. (2009). E-Commerce. New Jersey: Pearson Prentice Hall.

Mata, F. J. (1995). Information Technology and sustained competitive advantage: A resource-based analysis. MIS Quarterly, 19(4), 487. http://dx.doi.org/10.2307/249630

McKay, J. (2004). Strategic Management of e-Business. Brisbane: John Wiley \& Sons.

Normann, R. A. (1993). From value chain to value constellation: Designing attractive strategy. Harvard Business Review, 71(4), 65-77.

Nunally, J. (1978). Psychometric Theory (2nd ed.). New York: Mc Graw Hill Co. Inc.

O'Brien, M. (2008). Management Information System. McGraw Hill, Eight Edition.

Powell, T. A. (1997). Information Technology A Competitive Advantage: The role of Human, Business and Technology Resources. Strategic Management Journal, 18(5), 375-405. http://dx.doi.org/10.1002/(SICI)1097-0266(199705)18:5<375::AID-SMJ876>3.0.CO;2-7

Rezvani, M. G. (2011). Strategic Planning: A Tool For Managing Organizations in Competitive Environments. Australian Journal of Basic and Applied Sciences, 5(9), 1537-1546.

Rogers, E. (1995). Diffusion of Innovations (3rd ed.). New York, NY: The Free Press.

Rogers, E. A. (1993). Measuring Organization Performance in Strategic Human Resource Management: Looking Beyond the Lamppost. GAHRS Working Paper Series, 135.

Saeed, K. G. (2005). The Relationship of E-commerce Competence to customer value and firm performance: An Empirical Investigation. Journal of Management Information System, 22(1), 223-256.

Scupola, A. (2008). Conceptualizing Competences in E-services Adoption and Assimilation in SMES. Journal of Electronic Commerce in Organization, 6(2), 76-91. http://dx.doi.org/10.4018/jeco.2008040105

Sekaran, U. (2003). Research Methods for Business-A Skill Building Approach (4th ed.). New York, NY: Wiley.

Sekaran, U. A. (2011). Research Methods for Business: A Skill Building Approach. UK: John Wiley \& Sons.

Srivasta, R. K. (2001). The Resource-based View and Marketing: The Role of Marketing Asset in Gaining Competitive Advantage. Journal of Management, 27.

Tow, C. (2004). Development of E-commerce Capability Instrument Using Instrument The Resource-Based View Perspective And Its Application To Firm-Level Performance. University of South Australia: Proquest Digital Disertation.

Trochim, W. (2001). The Research Methods Knowledge Base. Cincinnati: Atomic Dog.

Wade, M. (2004). Review: The resource-based view and information systems research: Review, extension, and suggestions for future research. MIS Quarterly, 107.

Wen, H. L. (2004). Measuring E-Commerce Efficiency: a data analysis (DEA) approach. Industrial Management \& Data Systems, 103(9), 703-710. http://dx.doi.org/10.1108/02635570310506124

Windahl, C. A. (2006). Developing integrated solutions: The importance of relationships within the network. Industrial Marketing Management, 35(7), 806-818. http://dx.doi.org/10.1016/j.indmarman.2006.05.010

$\mathrm{Wu}$, F. M. (2003). An analysis of e-business adoption and its impact on business performance. Journal of Academy of Marketing Science, 31(4), 425-447. http://dx.doi.org/10.1177/0092070303255379 
Zhu, K. (2004). The complementarity of information technology infrastructure and e-commerce capability: A resource-based assessment of their business value. Journal of Management Information Systems, 21(1), 167.

\section{Copyrights}

Copyright for this article is retained by the author(s), with first publication rights granted to the journal.

This is an open-access article distributed under the terms and conditions of the Creative Commons Attribution license (http://creativecommons.org/licenses/by/3.0/). 